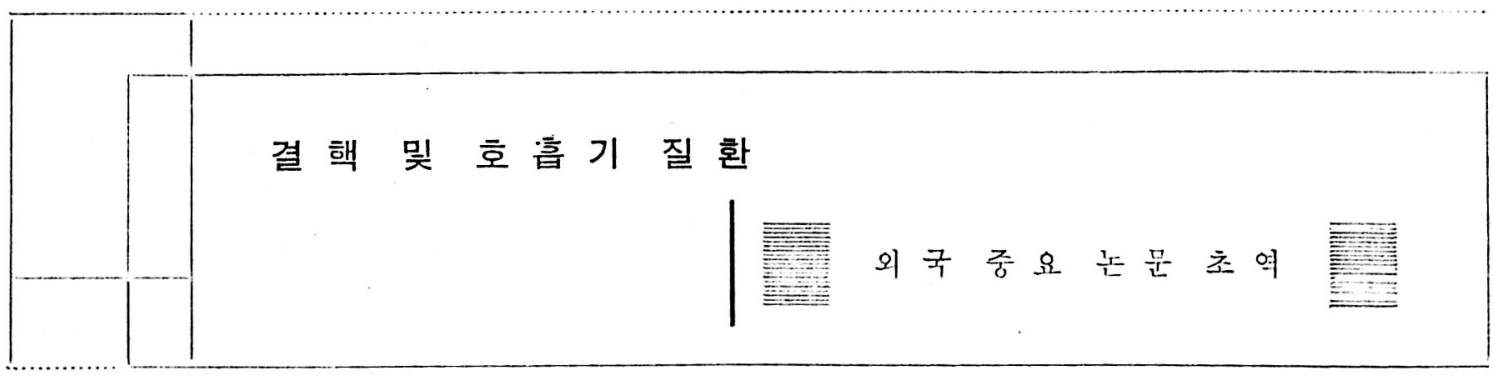

\section{A Hypothesis for Pulmonary Clearance and It's Implication}

\section{by Kilburn, K.II.}

Am. Rev. Resp. Dis.,

$1958-9,98: 449$

저자는 대분본의 호홈기진 환에 있이서 Pulmonary Clearance 죽 Ciliary Cello 국응이 중오한 의할을 할 것 이라는 짓을 좀 더 자세히 규병하고 어기에 데한 화신 한 가설을 실정해 두는 것이 좋을 것이라는 전제에서 다음과 같은 가신과 그의 뒷받침을 해설한 것이라고 하 겠다. 이러한 연구들은 최근에 홈연과 기관지엽, 훅은 기관지압의 발생분게와 관린해서 낞이 구명되고 있는 것을 이느정도 종함하고 또 자기들의 긴해물 칩가한 것 이라고 할 수 있다. 그런데 이것은 우러들이 않아야 할 중요한 dynamic histophysiology라고 셍각뮌 다.

\section{〈Hypothesis〉}

(1) 페포는 휴ㅇㅣㅣ된 비용해싱 익자(particle)나 세포(이 눔) 을 fluid film 위에 뜨게해서 포년 장력에 의해서 웅 모세포(cilia cell)가 있는 소기관기 쪽으로 이동시킨다.

(2) 이러한 청소작용이 실페하게 되는 깃이 이러가지 폐질한에 있어서의 중요한 녕적 과정이라고 할 수가 있 다.

이리한 두가지의 가설율 뒷받칩하기 위해서 다음과 같은 헤신을 저자는 하는 것이다.

\section{Clearance of Conducting Airways}

기관 과 기간시에는 짐액 분비를 하는 Goblet cell 한게 에 5 게의 융보세포가 있는 비율로 상피세포가 딖혀 있 다. 융보세포는 5-7

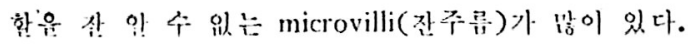

\section{$\diamond$ Mucus production}

gobluct cell운 야 $4 \mathrm{~m} l$ 가랑의 mucous gland volume을
갖이고 있고 보통 mucosal gland 보다도 더 진하고 군 적거리는 mucus를 분비한다.

\section{$\diamond$ Mucus Transport}

Cilia는 그 위룰 덮고 있는 액체가 없으비 청소운동 을 잘돗하고 또 하더라도 효과가 읶지난 일초에 17-2! 회 가량 움직이벼 이만의 운반속도는 동문에 따리서 $\mathrm{c}$ 르지 만 $1.0 \sim 3.5 \mathrm{~cm}$ per $\min$ 이다.

\section{$\diamond$ Sol and Gel Mucus}

Cilia 위에는 는 엑체가 덖혀 있는데 (이깃음 mucov blanket이라고 합) Cilia에 직접 닿는 부분은 농도가 9 은 watery sol portion이고 이 위에 농도가 놀을 visce elastic한 thick gel portion이 있이서 이 반은 sol laye 가 바르지 않도록 덖어주고 있고 또 이물이 침입하: 것을 방지하고 있다고 할 수도 있다. 그러니까 ciliasol portion 속에서 자유로 움직이고 그 위에 gel portic 음 바치 땅두되지가 띵눅으로 지나 갈 때에 땅의 포

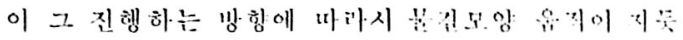
파상운동이 셍기고 그 위에 없어지 있는 이뉼은 이 결에 따라서 움직여지는 것이고 Cillia가 직경 비질 하는 것은 아니라는 것을 우리는 알 수 있다.

\section{$\diamond$ Volume of Secretion}

정상적으로 본비기는 홓ㅎㄱ기도의 본비망은 화실치 으나 싱인에서는 데략 $10 \mathrm{ml}$ 라고 할 수 있으머 이? 가레로 되이서 삩어 내지기도 하지반 또 대부분은 홉수 되는테 여기에 대해서는 아직 잘 모른다.

\section{$\diamond$ Hydration of Mucus}

음식물에 관련잆이 늘 정상랑이 유지되는 것은 ㄴ 이다.

\section{$>$ Compling of Alvealar to Mucociliary Clea}

이물이 페포에서 융모세포가 있는 기관지로 운 기 위해서는 포식동문에서는 우신 macrophinge나 : alar Type II or B Cello에 의해시 phagocytize ㄴ!! 다. 린베 개구리에쇠 보년 우선 이불이 물기롤 빈아서

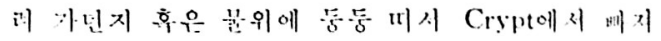
세 그. 얿에 ridge로 꼴려 갔다아 Cilia 위에 어x 
난.

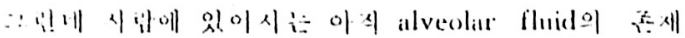

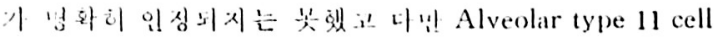

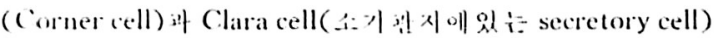
이 하이할 후 있을 것이라고 추측년다도 햇ㄷ.

\section{Inhaled Materials and Host Responses}

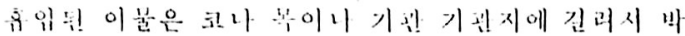
히넌시 혜포세포 free macrophage에 의해시 phagocytize 되어서 제기되는데 이때에는 립프나 현류 련 통해서 Reticuloendothelial system에 포착 되년시 Cilary action 에 의해서 칭소되던지 할 깃이다. 또 이 때에는 pharynx 에 또달한후 가래륜 낸으면 바깹으로 나오게 되고 그 맇지 않으년 식도로 해서 위장으로 가서 읙시 힐류속 으로 훔 누 될 수 있을 것이다.

\section{$\gg$ 폐의 변화}

이반이 침입하면 폐와 기간지에시는 톡히 goblet Cell 에 의해시 iㅗㅎ은 mucus가 분비 되지만 경 우에 따라서는 이불에 의해서 cilia cello이 상하고 따라서 칭소착용이

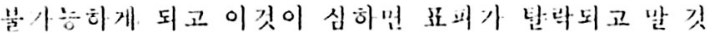
이나. 이리한 자극이 계속되면 goblet cello이 충식되고 mucus 본미가 더 방아지는데 결국엔 이깃이 오히려 부

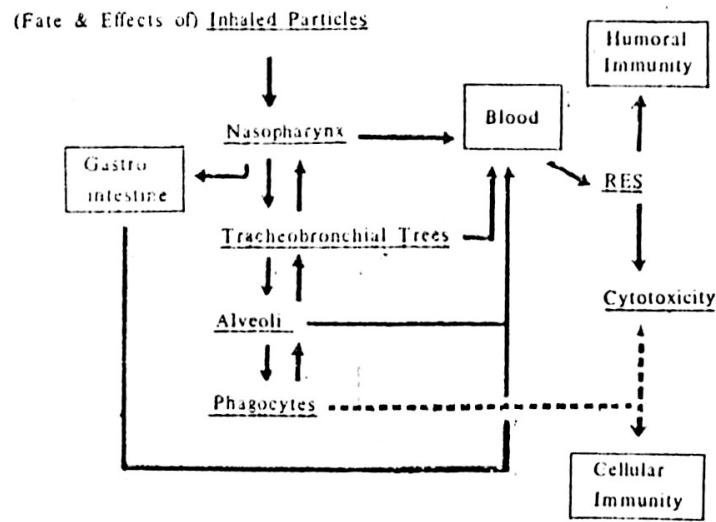

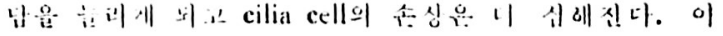

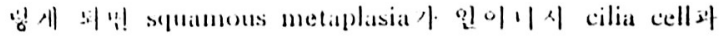
goblet cell 은 squamous cell 호 대치년다.

\section{Site of damage}

줌언에 의안 tobaceo tars나 녹싱까스의 피에가 오래

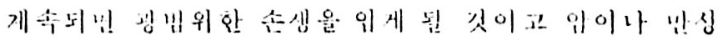

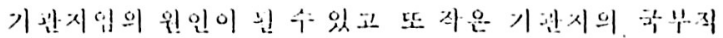
손상이 싱싰을 때에도 그. 부눈에시 allergic particle이 형 수뢰기 쉬우니과 덥증과 기관지 친시의 반싱이 가흥하다.

\section{Bronchiolitis의 경우}

작은기난지가 Virus나 그. 박에 이물에 의레시 상피 세포의 상해랄 난으면 이것이 mucus plug(마새)가 되 어서 그 부분에 분비물이 축적 힌다던시 Ventilation 과 gas exchange가 방혜된다. 이러한 상테가 오레 되먼 그. 부분이 fibroblastic proliferation에 의해서 아수 perma nent obstruction올 인으키세 회고 결국 그. 누년 labule에 Contraction shrink멸 보세 된다.

\section{Centrilobular emplysema의 경우}

아주 반초밤본의 손상이 오면 Centrilobular emphyse $\mathrm{ma}$ 의 원인이 뒨 수있다는 hypothesis 신면할 수가 있울 것이다.

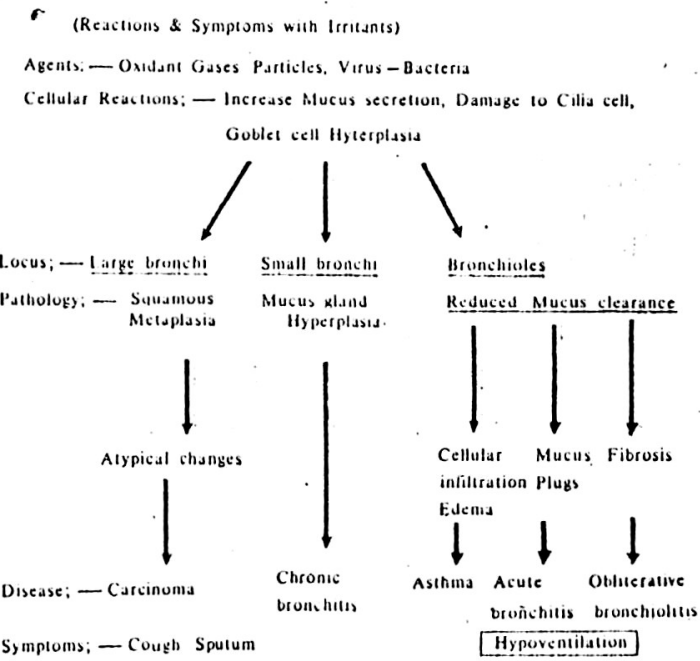

